
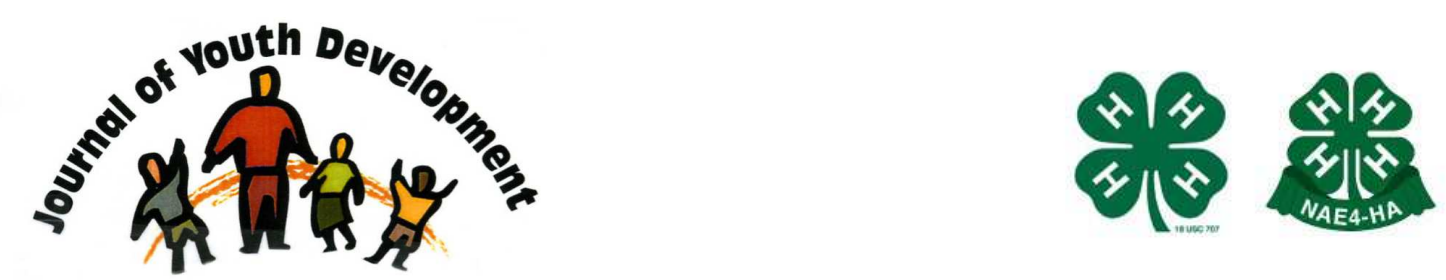

Bridging Research \& Practice

\title{
Integrating Youth into Community Development: Implications for Policy Planning and Program Evaluation
}

\author{
Rosemary V. Barnett \\ Department of Family, Youth, and Community Sciences \\ The University of Florida \\ Gainesville, FL 32611-0310 \\ rbarnett@ufl.edu \\ M.A. Brennan \\ Department of Family, Youth, and Community Sciences \\ The University of Florida \\ Gainesville, FL 32611-0310 \\ MABrennan@ifas.ufl.edu
}




\title{
JOURNAL OF YOUTH DEVELOPMENT \\ bridging research and practice

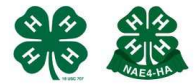

Volume 1, Number 2, September 2006

Article 0602FA001

\section{Integrating Youth into Community Development: Implications for Policy Planning and Program Evaluation}

\author{
Rosemary V. Barnett and M.A. Brennan \\ The University of Florida
}

As non-profits, volunteer groups, and nongovernmental organizations take on increasingly larger roles in contributing to local well-being, the active collaboration between youth and adults is vital to the longterm success of community development efforts. Similarly, as service activities become standardized components of high-school programs, youth are empowered to becoming long-term contributors to local development efforts. Through this process youth engage in shared citizenship, leading to greater investment in their communities. This research was based on the premise that youth, acting as central parts of the community development process, have the capacity to improve local well-being. It reflects input from 12 key informants and 418 youth who participated in a survey conducted on the development issues contributing to their involvement. The findings of this study provide insights into the factors most directly shaping youth attitudes and involvement in their communities, as well as presenting direct implications for applied use.

\section{Introduction}

A direct need exists for program and policy planners to better understand the role, impact, and possibilities presented by youth involvement in the community development process. Historically, youth input in decision-making, problem-solving, local action, and evaluation in communities has received only limited attention. However, recent trends suggest that youth are 
playing an increasingly important role in the development of their communities (Sherrod, Flanagan \& Youniss, 2002).

As non-profits, volunteer groups, and nongovernmental organizations take on larger roles in contributing to local well-being, the active collaboration between youth and adults is vital to the long-term success of development efforts. Similarly, as community service activities become a more standardized component of high school programs, youth are increasingly being put in the position where they can become long-term contributors to local development efforts.

Opportunities and responsibilities arise from these interactions that allow communities to become active participants in shaping their youth for more productive outcomes. Through this process youth become engaged in a shared citizenship, leading to greater investment in their communities beginning at an earlier age. Partnerships between educators, youth, and community leaders can enhance this learning process of youth in formal and informal ways.

The importance of youth involvement is particularly relevant in Florida, as communities throughout the state face extensive growth pressures, significant socio-demographic changes, and a growing youth population. Such conditions suggest an important role for youth to play in local planning and decision-making. The involvement of youth, and their active collaboration with adults, contributes to local community development, while presenting opportunities for personal self-growth, skill enhancement, and leadership development. Previous research suggests that successful youth/adult partnerships encourage youth to develop the capacity to serve in organizations and be active community leaders (Brennan, Barnett \& Lesmeister, 2006).

\section{Review of Literature}

The study of active youth involvement in community development is in many ways an underdeveloped field of inquiry. Both, the community and youth can benefit greatly from the involvement of young residents in all aspects of the community development process (Scales \& Leffert, 1999; Brennan, Barnett \& Lesmeister, 2006). Equally important, young people can become empowered to be problem-solvers, decision-makers, and committed leaders who will lead community development efforts in the future. Lastly, through the active interaction of youth and adults, a more representative voice is provided that reflects the diverse needs and wants of the community.

\section{Community and Youth Development}

The development of community invokes a variety of images. Many definitions tend to emphasize locality, structural components, and other characteristics that reflect a shared territory. Community is much more than a geographic location however. It is a social and psychological entity that represents a place, its people, and their relationships (Wilkinson, 1991; Luloff and Bridger, 2003; Theodori, 2005). Community, from an interactional viewpoint, emerges from the conscious experiences of its members. It is a dynamic field of interaction rather than a rigid system or a simple piece of geography. The development of community is a dynamic process involving all segments of the locality, including the often forgotten younger members. The key component to this process is found in the creation and maintenance of channels of interaction and communication among diverse local groups that otherwise are directed toward their more limited interests. Through these relationships, individuals interact with one another, and begin to mutually understand common needs and create awareness of opportunities for involvement. Where these relationships can be established and maintained, increases in local adaptive capacities materialize and community can emerge. 
All localities are composed of numerous distinct local groups (business, education, civic, cultural, etc.) whose members act to achieve individual interests and goals. Community, or the community field as it is often referred to, connects these diverse groups and serves to coordinate individual groups into purposive community-wide efforts. It cuts across class lines, organized groups, and other entities within a local population by focusing on the general and common needs of all residents. From this interactional perspective, community is a constantly changing environment motivated by voluntary community action and social interaction (Wilkinson, 1991; Swanson, 2001; Luloff \& Bridger, 2003).

As residents and groups interact over issues important to all of them, what has come to be known as community agency emerges (Luloff \& Bridger, 2003; Theodori, 2005). Agency reflects the building of local relationships that increase the adaptive capacity of local people within a common territory. Agency is therefore reflected in the capacity of people to manage, utilize, and enhance those resources available to them in addressing local issues (Wilkinson, 1991; Luloff \& Bridger, 2003; Brennan, 2005).

While much of the attention given to building local capacities is often focused toward adults and civic organizations, youth are an increasingly visible and active component in community development efforts. The community is the first entity that all of us encounter beyond our families. It is important, therefore, for youth to have clearly defined roles and opportunities, which allow them to actively participate in their communities rather than having passive roles. Relationships between youth and community building are a key long-term involvement in community development efforts (Brennan, Barnett \& Lesmeister, 2006).

\section{Youth Engagement}

Civic engagement, such as civic education and opportunities for involvement in school extracurricular activities, are an important element of community involvement for youth (Sherrod, et al., 2002), as they represent a microcosm of the larger society where youth may practice skills. Other aspects, such as teacher behavior, school climate, instructional style that promotes dialogue and discussion, and school policies (Flanagan \& Van Horn, 2003) may help define good citizenship, therefore, promoting youth involvement and serving as indirect motivators.

Citizenship, defined frequently by youth as "good behavior, doing what you are expected to do, obeying laws, and so on" has become a key developmental component toward motivating youth to engagement through volunteerism (Flanagan \& Faison, 2001; Sherrod, et al., 2002). The developmental aspects of learning concepts of citizenship have been explored from a focus on obedience and support of status quo to using good judgment to form knowledge of one's rights and responsibilities (Torney-Purta, et al., 2001). Motivators for civic engagement, hence for citizenship, have been identified as important factors in community youth development literature (Youniss \& Yates, 1997; Flanagan \& Van Horn, 2001; Eccles \& Gootman, 2002; Flanagan \& Van Horn, 2003). By learning concepts of citizenship, youth build practices and processes that link to adult civic engagement (Verba, et al., 1995; Youniss, et al., 1997). When youth are able to contribute to some set of shared norms or values, they are further able to identify their own set of interests within the greater social framework (Sherrod, et al., 2002).

\section{Youth Leadership for Community Program and Policy Planning}

Opportunities for leadership are necessary in order to develop young people and prepare them to be contributing adults in their communities. As schools and other social institutions consider how to integrate youth into the process of community development, it is important to ensure that conditions exist which will support the development of youth into healthy, contributing 
adults. These contextual arenas will allow youth and adults to partner in addressing many social problems, leading to greater understanding and shared norms and values. Adults must recognize that adolescent's lives are also impacted by multiple systems, and as adults, they need opportunities to lead and represent within their greater community setting toward program and policy planning, implementation, and evaluation (Larson, et al., 2006). The merging of youth development and community building has been at the core of recent youth engagement literature (Nitzberg, 2005; Kubisch, 2005; Cahn \& Gray, 2005; Lynn, 2005). Such has identified that youth must be fully engaged and involved in change efforts if they are to function as effective members of society (Nitzberg, 2005). By recognizing that youth have the capacity to lead, adults can provide important support in shifting youth leadership development from a skill based orientation to an essential investment in the future (Larson, et al., 2006).

It is the merging of youth development and community development that enables youth leadership to emerge. Adolescents should become actively involved in the design of community programs and policies. Their level of cognitive, moral and social development enables them to rise to more complex challenges as they transition to adulthood and the responsibilities that come along with it (Berk, 2005). Such involvement also sets the stage for long-term involvement, leadership development opportunities, and ownership of community development efforts. In order to develop youth leadership with organizational structures, certain specific "necessary conditions" must be in place for youth leadership to work effectively. Mechanisms for advancing youth into responsible roles include training youth to develop specific skills (such as reading budgets and working on committees) and training adults to explore their preexisting assumptions and stereotypes about youth as community leaders (Zeldin et al., 2000).

Three developmental stages of youth leadership have been prescribed as awareness, interaction and mastery (vanLinden \& Fertman, 1998). Five dimensions of leadership that are within each of these three stages include Leadership Attitude, Leadership Information, Communication Skills, Decision-Making Skills and Stress Management. Training in specific skill areas, such as setting realistic goals, being able to delegate responsibility, setting priorities, using information to solve problems, managing conflict, and considering input from all group members, are important for youth to learn in a community leadership setting (Smith, Genry \& Ketring, 2005). Further training in civic minded skills, such as understanding the legal or policymaking process, and how to work on community-based committees to address social problems, will enhance building strong youthadult relationships and open doors for youth leadership on a broader contextual arena.

Youth leaders can also play important roles, such as identifying youth issues, developing youth programming, leading youth program delivery, and representing youth in their community (Huber, et al., 2003). As more meaningful involvement unfolds, organizational and community changes that reflect the priorities of youth will stimulate greater participation by youth in future decisionmaking. Youth, adults, schools, organizations, and communities may all potentially benefit from a greater investment in youth as they become engaged in leadership roles within their community (Larson, et al., 2006).

\section{Methods}

This research was designed to improve the understanding of, and ability to measure, the factors shaping youth involvement in community development efforts. To accomplish these goals, multiple research methods were utilized. Primary data collection took the form of survey research, key informant interviews, and focus group discussions with youth and development professionals involved in community development during summer 2005. 


\section{Data Collection Methods}

Initial data collection included key informant interviews with youth, 4-H program development agents, and adults actively involved with youth/adult partnerships. Key informants are individuals who, as a result of their knowledge, experience, or social status, can provide insights and access to information valuable in understanding issues, impacts, and needs (Krannich \& Humphrey, 1986; Schwartz, et al., 2001). In June 2005, twelve key informant interviews were conducted. These included 4-H administrators, educators, youth participants, and program administrators that include youth in their efforts. Interviews facilitated our understanding of the context of attitudes and actions, as well provided information that would not have been evident from survey or secondary data.

Key informants were particularly helpful in the development of questions for use in the survey. Subsequent to these interviews, quantitative data was obtained from Florida teen 4-H participants through a self-administered questionnaire. A modified Total Design Method (TDM) was used in these surveys (Dillman, 2000). This method stressed a precise methodology, including specialized design and personalization. Questionnaires were distributed in group settings to all participants to help insure a high completion rate.

Data collection took place at four different 4-H events between June and September 2005. Included were the Florida 4-H Legislature, State 4-H Congress, and two "Learning and Leading" workshops. A total of 679 youth ages 12-18 took part in these events. Participants in these events, while not representative of all youth in Florida, were statistically representative of the overall 4- $\mathrm{H}$ teen population in Florida (Isaac \& Michael, 1997). Completed and usable questionnaires were obtained from 418 respondents, representing a response rate of $62 \%$. This response rate and the number of usable questionnaires returned were more than sufficient to statistically represent 4-H Youth in Florida (Isaac \& Michael, 1997).

Variables Included in the Analysis

Survey data was used to assess the relationships between youth attitudes and behaviors and the youth community involvement. Community involvement was measured with a series of questions that asked respondents about their frequency and level of participation in community activities.

Measures included the following items:

(1) the number of clubs, groups, and/or organizations to which the respondent belonged (number of clubs/organizations)

(2) hours per month spent on organized activities with other members of this community (number of hours)

(3) a self-ranking description of the respondent's level of involvement in local activities, events, or organizations ( 1 - not at all active to 4 - very active)

(4) membership on a community board (no/yes)

(5) membership on a community council (no/yes) and

(6) membership on a community committee (no/yes). 
These variables were combined into a composite score that served as a single dependent variable. ${ }^{1}$ Similar items have been used in previous research to measure social participation (Claude et al., 2000; Theodori, 2000; Brennan, 2005).

According to the social participation literature, a variety of factors influence community agency and shape the context in which it emerges. Among those included as independent variables in this analysis are sociodemographic characteristics, ${ }^{2}$ local connections and networks, ${ }^{3}$ capacity building for youth leadership, ${ }^{4}$ methods for fostering youth enthusiasm and investment in community activities, ${ }^{5}$ opportunities for personal/professional growth, ${ }^{6}$ and youth linkages to program and policy planning. ${ }^{7}$

\footnotetext{
${ }^{1}$ The data were factor analyzed using several models/rotations (principal axis factoring and least squares methods with a varimax, quartimax, and direct oblimin rotations). The criteria established in advance of the selection of factor items were: a factor loading of .35 or higher; at least a .10 difference between the item's loading with its factors and each of the other factors; and interpretability (Kim \& Mueller, 1978). In all analyses, only one factors was identified which had eigenvalues of greater than 1.0. Cronbach's Alpha for this index was .79.
}

${ }^{2}$ Sociodemographic variables included age (in years), gender, number of residents in the household, length of residences (years and months), rural/urban location (1 - farm to 6 - large city), and household income level (1lower income to 3 - higher income).

${ }^{3}$ Local connections and networks included: "How often do you see or meet with at least one of the following types of people? Immediate family, Extended family, Close friends, Acquaintances, Neighbors, and with others through community clubs/groups." For each, the respondents were given response options of: (1) never, (2) a few times a year, (3) once a month, (4) a few times a month, (5) once a week, and (6) more than once a week.

${ }^{4}$ Capacity building for youth leadership index was composed: Consider the group/organization that you are most involved in. How strongly do you agree or disagree with the following statements? I'm actively involved in decision making, I'm actively involved in policy making, My community values youth in working toward solutions, I have a large say in how the organization grows, My input has value, and I influence the community by being in this organization. Response options ranged from 1 - Strongly Disagree to 5 -Strongly Agree influence. As with the dependent variable, a series of factor analysis were conducted using established selection criteria. In all analyses, a one factors model was identified. Cronbach's Alpha for this index was .87.

${ }^{5}$ Methods for fostering youth enthusiasm and investment in community activities were measured by: People become involved in community activities for many reasons. I participate in community activities because: I believe that the community needs new ideas, I believe that the community needs better services, I am dissatisfied with the way things are, and I enjoy local politics, and I feel it is my public duty as a citizen. Response options ranged from 1 Strongly Disagree to 5 - Strongly Agree. Effective youth/adult partnerships can run into problems. How do the following affect your decision to become actively involved in your community? No identified role for youth in organizations, Not being assigned to committees, and Organizations not allowing youth to vote. Response options ranged from 1 - not a problem to 5 - major problem.

${ }^{6}$ Opportunities for personal/professional growth were measured by: How does each of the following influence your decision to become involved in community activities? Receiving recognition and local prestige, Having the opportunity to use my skills, Getting acquainted with people, Having the opportunity to develop new skills, Influencing the behavior of others, Having the opportunity to set an example for others. Response options ranged from $1=$ no influence to $5=$ strong influence. Also included was: How do the following affect your decision to become actively involved in your community? Not having skills to offer. Response options ranged from $1=$ not a problem to $5=$ major problem. This item was reverse coded for analytical proposes. In all analyses, a one factors model was identified. Cronbach's Alpha for this index was .75.

${ }^{7}$ Youth linkages to program and policy planning were measured by: People have different opinions regarding the importance and impact of youth volunteers on the community. How strongly do you agree or disagree with the following statements? Youth volunteers improve the local quality of life, The local economy is improved by youth volunteers, Youth volunteers help focus attention on local conditions, Youth as volunteers provide important local services, Youth volunteers don't actually do much in my community (reverse coded), and Local groups rely heavily on youth volunteers. Response options ranged from 1 - strongly disagree to 5 strongly agree. In all analyses, a one factors model was identified. Cronbach's Alpha for this index was .73. 


\section{Analysis}

In this study, a series of multiple regression models were estimated to assess the partial effects of each predictor on youth community involvement (Table 1). These models focus on each conceptual area individually. A final model considered all independent variables together, and was ultimately reduced, in order to obtain the most parsimonious model. Individually, all conceptual areas played a role in shaping community involvement. Leadership capacity and youth investment were the greatest predictor of community involvement $\left(R^{2}=.23\right.$ and .18 respectively). Individual investment items and the leadership capacity index were all positively related to youth community involvement.

Among the sociodemographics that were positive and significantly related were age and household income. Rural/urban location was also significant, with rural youth being more involved. These items accounted for $11 \%$ of the variation in the model $\left(\mathrm{R}^{2}=.106\right)$. In the case of the local networks variables, only interacting with others through social clubs/organizations was related to youth involvement and represented $11 \%$ of the variation in the model $\left(R^{2}=.113\right)$.

Lastly, personal/professional growth activities and the program/policy index also played a role in shaping youth involvement. Both were positively related to the dependent variable. These represented $12 \%\left(R^{2}=.118\right)$ and $13 \%\left(R^{2}=.128\right)$ of the variation in the model respectively. 
Table 1

Comparison of Eight Multivariate Models on Youth Involvement in their Communities

\begin{tabular}{|c|c|c|c|c|c|c|c|c|}
\hline & Model 1 & Model 2 & Model 3 & Model 4 & Model 5 & Model 6 & Model 7 & $\begin{array}{l}\text { Reduced } \\
\text { Overall }\end{array}$ \\
\hline \multicolumn{9}{|c|}{-- Standardized Regression Coefficients -- } \\
\hline \multicolumn{9}{|l|}{ Demographic Variables } \\
\hline Gender (males $=1$ ) & -.070 & & & & & & -.022 & \\
\hline Age & $.248 * * *$ & & & & & & $.183 * * *$ & $.179 * * *$ \\
\hline Length of residence & .085 & & & & & & .046 & \\
\hline Household size & .054 & & & & & & .033 & \\
\hline Urban/Rural location & $-.101 *$ & & & & & & $-.089 *$ & \\
\hline Household income & $.134 * *$ & & & & & & .066 & \\
\hline \multicolumn{9}{|l|}{ Local Networks } \\
\hline Immediate family & & .029 & & & & & .060 & \\
\hline Extended family & & .070 & & & & & .050 & \\
\hline Acquaintances & & .088 & & & & & .039 & \\
\hline Close friends & & -.044 & & & & & -.045 & \\
\hline With others in clubs/groups & & $.290 * * *$ & & & & & $.151 * * *$ & $.164 * * *$ \\
\hline Neighbors & & .056 & & & & & -.002 & \\
\hline Leadership Capacity Index & & & $.482 * * *$ & & & & .277*** & $.300 * * *$ \\
\hline & & & & & & & & \\
\hline \multicolumn{9}{|l|}{ Youth Investment Index } \\
\hline Need for new ideas & & & & $.153 * *$ & & & .053 & \\
\hline Need for better services & & & & $.131 *$ & & & .044 & $.110 * *$ \\
\hline Dissatisfaction with local life & & & & .029 & & & .065 & \\
\hline Enjoying local politics & & & & $.166 * * *$ & & & .117 & $.112 * *$ \\
\hline Public duty & & & & $.165 * * *$ & & & -.038 & \\
\hline Identified role for youth & & & & -.036 & & & -.057 & \\
\hline Committee assignments & & & & .065 & & & .044 & \\
\hline Youth voting & & & & -.078 & & & -.030 & \\
\hline $\begin{array}{l}\begin{array}{l}\text { Personal/Professional } \\
\text { Growth }\end{array} \\
\end{array}$ & & & & & $.347 * * *$ & & $.104 *$ & $.115 * *$ \\
\hline Program/Policy Index & & & & & & $.361 * * *$ & \begin{tabular}{l|}
$.125 * * *$ \\
.12
\end{tabular} & $.179 * * *$ \\
\hline & & & & & & & & \\
\hline $\mathrm{R}^{2}$ Adjusted & .106 & .113 & .231 & .179 & .118 & .128 & .391 & .390 \\
\hline Fvalue & $7.87 * * *$ & $9.26 * * *$ & $119.64 * * *$ & $11.27 * * *$ & $54.85^{* * *}$ & $59.90 * * *$ & $10.58 * * *$ & $32.26 * * *$ \\
\hline Cases & 349 & 391 & 396 & 378 & 401 & 402 & 344 & 344 \\
\hline * significant at the .05 level & \multicolumn{8}{|c|}{ ** significant at the .01 level } \\
\hline
\end{tabular}

All variables were entered into the full model (Model 7). Seven were statistically significant and the model accounted for $39 \%$ of the variance (Adjusted $\mathrm{R}^{2}=.391$ ). However, since this model contained numerous nonsignificant variables, a more parsimonious reduced stepwise model was developed consisting of only the significant variables (Reduced Model). This model showed seven significant variables and accounted for $39 \%$ of the variance (Adjusted $\mathrm{R}^{2}=.390$ ).

In the reduced model, seven variables were positively related to the dependent variable - age, interacting with others through clubs/groups, the leadership capacity index, recognition of a 
need for better services, an enjoyment of local politics, the personal/professional growth index, and the program/policy index. As each of these items increased, level of youth community involvement increased.

\section{Implications, Recommendations, and Conclusions}

This study was based on the premise that youth, acting as central parts of the community development process, have the capacity to improve local well-being. It reflects input from 12 key informants and 418 active youth who participated in a survey conducted on the community development issues shaping their involvement. The findings of this study provide insights into the factors most directly shaping youth attitudes and involvement in their communities, as well as presenting direct implications for applied use.

Each of the significant variables identified present specific implications for program and policy development. Taken together they present a clear picture of efforts that can foster effective youthadult partnerships, increase youth leadership, and better include youth in the community development process. Of the specific demographic variables, age was found to be significant. Age reflects the increased ability of youth to participate in community development as their cognitive, physical, moral, emotional and social development increases. This supports the notion that adolescents, particularly late adolescents, are capable and willing to learn leadership roles to improve communities.

Further, local connections and networks were found to be significant in explaining involvement. This can be interpreted that as more interaction with adults and other youth is encouraged through leadership building and increased involvement in local issues, youth will continue to participate. Youth need social interaction if they are to flourish and increased involvement supports this developmental aspect.

Capacity building for youth leadership was included in an index and found to be a predictor of community involvement. This analysis explored the influences related to input, decision making and the value the community places on youth involvement on whether youth become involved in community activities. Larson (2000) found that when youth are involved in activities that have intrinsic motivation, that are challenging enough to engage their attention, and that occur over time, they develop initiative. The positive relationship between the index and the dependent variable support the need for youth capacity building to be considered by community leaders. Community and youth development leaders may focus on building the kinds of opportunities that would allow youth to set examples to other youth, providing leadership development training, allowing youth to take on increased leadership roles with other younger or less trained youth, and continue to build their community development abilities by enhancing their own moral and civic development skills, while simultaneously developing other necessary social skills.

Certain investments were also found to significantly relate to involvement, specifically related to methods for fostering youth enthusiasm. By allowing youth the opportunity to provide new ideas, they would be more likely to be active participants in community development efforts. This sends youth the message that they are welcome in the decision-making process, that they are capable of good decision-making, and that they have the knowledge and understanding of issues to significantly contribute to discussions. Similarly, youth that enjoy local politics and have a desire for public duty will be more likely to become involved, as well as those who feel that the community has a need for better services. 
Opportunities for personal/professional growth were found to be positively related to community development and relate to being able to develop and use skills, influence the behavior of others, and set an example. Getting acquainted with other people and being recognized locally are also important aspects for youth as measured by this index.

Youth linkages to program and policy planning were found significantly related to involvement and this supports previous research findings that show youth are more likely to actively be involved when they believe that their actions make a difference and are having an impact (Scales and Leffert, 1999). By promoting the impact that youth have and recognizing their efforts, youth will become more visible players in the community development process and evolve into more dynamic roles as empowerment occurs.

Based on these findings the following eight general steps are suggested to enhance and increase the level of involvement of youth in community development efforts:

1. Provide youth opportunities to become long-term contributors to community organizations. Consider new ways to involve youth and allow them to provide input in decision-making, problem solving and action-taking activities within local organizations, non-profits, volunteer groups, youth programs and nongovernmental organization. This may include putting youth on advisory boards, giving them voting privileges, and serving on committees. This step reflects the significance of local networks and may require more active collaboration with youth than before in order to engage them in ways that will open doors for them to contribute. As youth engage in more sustained positive relationships with adults, other youth, and community organizations, they will learn that they are valued citizens of their communities.

2. Present opportunities for personal self-growth, skill enhancement, and leadership development for youth. This step reflects the significance of personal/professional growth. This may occur through increasing involvement of youth with adults in active collaboration toward local community development. Integrating youth into committees with adults as mentors and guides in this process will enable them to build the leadership skills and personal characteristics necessary for future adult involvement. Training in areas such as conflict management, stress management and communication skills will lead to changes in attitudes and respect as youth become more confident in their skill level.

3. Encourage youth to develop the capacity to serve in organizations and become community leaders. Adults must first recognize and develop their own existing capacities, motivations and barriers to partnering with youth within organizations and local governmental agencies. Once existing levels are determined, adult outreach to youth through schools, youth organizations, and youth groups can connect adults to youth in order to increase youth leadership capacities. Adults can and should inform youth of their value and the need for their service. This step reflects the significance of youth leadership capacity and youth investment. It may be done by letting youth know that their involvement is valued, letting the community and public at large know that youth are doing a good job, and recognizing them formally through recognitions that officially thank them for their service. 
4. Engage youth actively so they may provide new ideas and voices that will stimulate enthusiasm and investment in community structures. This step relates to the significance of youth investment through an enjoyment of local politics for greater youth involvement. Adults must understand the invaluable impact of youth involvement in order to engage youth. This involves respecting their own youth culture, getting youth involved at all levels, and actively soliciting their input, rather than keeping their involvement on a surface-level relationship that is strictly limited to task oriented volunteerism. If youth are empowered to become full partners in the community development process, they become more invested in long-term participation and contribution to their community.

5. Form connections to local schools and teachers, particularly with those who actively interact with youth in community issues. This step directly relates to the significance of local networks. This may include the obvious civic education oriented approach, such as with student government groups, as well as the more subtle community building oriented approach like school entrepreneurship and business education organizations that promote life skills, fiscal responsibility, and leadership. By introducing community needs and opportunities to meet these, youth participation can be encouraged and reinforce the importance of involvement in community action and policy making. Tiebacks to citizenship, entrepreneurship, and civic education in the community will provide classroom opportunities connected to real world scenarios. Such connections provide teachers and students with learning opportunities, allowing youth to practice these abstract constructs in community development application.

6. Link youth to comprehensive planning and policy efforts in their communities. This step reinforces youth linkages to program and policy planning and can be accomplished by involving youth in the examination of existing policies as well as in the evaluation potential policy alternatives. By fostering youth input into policy review and development, youth will move from their role of often inactive citizens to fully engaged stakeholders. This powerful connection to real community issues will involve youth not only in present decisions, but in future outcomes. By empowering youth to become full partners in the community development and policy making process, they will become more invested in long-term participation and contribution to community programs/policy.

7. Allow youth to identify their own interests within the greater social framework of community development and policy making. As youth are brought into organizations and civic roles that they have traditionally been excluded from, they can participate in active and equal decision-making at multiple levels. This step relates to the significance of youth linkages to policy and program development. An increased exposure to shared norms/values through discussion of community issues and concerns will encourage youth to consider where their interests lie. Such deliberation will encourage them to seek activities where they can create positive change for greater good. These collaborations will also lead to skill enhancement and confidence building, allowing them to overcome feeling any intimidation with being involved, which will help them as they navigate toward adulthood.

8. Involve youth in confronting more serious social problems and conditions that will allow them to see themselves as community development agents capable of transforming their environments. By transforming youth from passive citizens waiting for adulthood, to active citizens engaging in social change, this step reinforces that youth 
will have a voice in decisions that transform policies, make institutions more accountable, and affect their lives. This can be reinforced by adult partnerships that value youth and recognize the importance of their contributions while providing opportunities that build community.

\section{Conclusion}

Community involvement is central to the development of community. From this perspective, community development is facilitated by the ability of local people to mobilize resources to address local needs. Youth are in a position to be the stable and long-term contributors that help guide this process. Youth represent a vast and often untapped resource, for immediate and long-term community development efforts. They also provide an invaluable resource for program planning and effective evaluation. Through their collaborations with adults and organizations, youth achieve skill enhancement, confidence building, and leadership development. The important role of youth in community development and their motivations for this kind of civic engagement remains an important research and program development focus. With such knowledge, youth and community workers can better understand how to maximize these powerful resources and enhance local development efforts in both the short and longterm.

\section{References}

Berk, L. 2005. Child Development. Boston, MA: Allyn \& Bacon.

Brennan, M.A., Barnett, R., and Lesmeister, M. 2006. Enhancing Leadership, Local Capacity, and Youth Involvement in the Community Development Process: Findings from a Survey of Florida Youth. Journal of the Community Development Society. (in press).

Brennan, M.A. 2005. Volunteerism and community development: A comparison of factors shaping volunteer behavior in Ireland and America. Journal of Volunteer Administration 23(2): 20-28.

Cahn, E.S. \& Gray, C. 2005. Using the coproduction principle: no more throwaway kids. Putting Youth at the Center of Community Building. New Directions for Youth Development 106: Summer 2005.

Claude, L., Bridger, J. and Luloff, A.E. 2000. Community well-being and local activeness. In P. Schaeffer and S. Loveridge (eds.), Small Town and Rural Economic Development: A Case Studies Approach. Westport, CT: Praeger.

Dillman, D. 2000. Mail and Internet Surveys. New York, NY: Wiley and Sons.

Eccles, J., \& Gootman, J. 2002. Community programs to promote youth development. Report of the Committee on community-level programs for youth, of the National Research Council and Institute of Medicine. Washington, DC: National Academy of Sciences.

Flanagan, C.A. \& Faison, N. 2001. Youth civic development: Implications for research for social policy and programs. Social Policy Reports, no.1, 2001. 
Flanagan, C. \& Van Horn, B. 2001. Youth civic engagement: Membership and mattering in local communities. Focus. Davis: 4-H Center for Youth Development, University of California.

Flanagan, C. \& Van Horn, B. 2003. Youth civic development: A logical next step on community youth development. In Villarruel, F.A., Perkins, D.F., Borden, L.M. \& Keith, J.G., (eds.)

Community Youth Development. Thousand Oaks, CA: Sage, pp. 273-296.

Huber, M.S.Q., Frommeyer, J., Weisenbach, A. \& Sazama, J. 2003. Giving youth a voice in their own community and personal development. In Villarruel, F.A., Perkins, D.F., Borden, L.M. \& Keith, J.G., (eds.) Community Youth Development. Thousand Oaks, CA: Sage, pp. 297-323.

Isaac, S. \& Michael, W. 1997. Handbook in Research and Evaluation. EdITS Publishers, San Diego, CA.

Kim, J. \& C. Mueller. 1978. Factor Analysis: Statistical Methods and Practical Issues.

Beverly Hills, CA: Sage Publications.

Krannich, R. \& Humphrey, C. 1986. Using key informant data in comparative community research: an empirical assessment. Sociological Methods and Research 14: 473-493.

Kubisch, A. 2005. Comprehensive community building initiatives-ten years later: What we have learned about the principles guiding the work. Putting Youth at the Center of Community Building. New Directions for Youth Development 106: Summer 2005.

Larson, R. 2000. Toward a psychology of positive youth development. American Psychologist, 55(1): 170-183.

Larson, R.W., Wilson, S. \& Mortimer, J.T. 2006. Adolescence in the $21^{\text {st }}$ Century: An International Perspective. http://www.s-r-a.org/conclusions.html.

Luloff, A.E., \& Bridger, J. 2003. Community agency and local development. In D. Brown \& L. Swanson (eds.), Challenges for rural America in the twenty-first century. University Park: Pennsylvania State University Press.

Lynn, A. 2005. Youth using research: Learning through social practice, community building, and social change. Putting Youth at the Center of Community Building. New Directions for Youth Development 106: Summer 2005.

Nitzberg, J. 2005. The meshing of youth development and community building. Putting Youth at the Center of Community Building. New Directions for Youth Development 106: Summer 2005.

Scales, P.C. \& Leffert, N. 1999. Developmental Assets. Minneapolis, MN: Search Institute.

Schwartz, M., Bridger, J., \& Hyman, D. 2001. A validity assessment of aggregation methods for multiple key informant survey data. Journal of the Community Development Society 32(2): 226237.

Sherrod, L.R., Flanagan, C. \& Youniss, J. 2002. Dimensions of Citizenship and Opportunities for Youth Development: The What, Why, When, Where and Who of Citizenship Development. Applied Developmental Science 6(4): 264-272. 
Smith, T.A., Genry, L.S., \& Ketring, S.A. 2005. Evaluating a youth leadership

Swanson, L. 2001. Rural policy and direct local participation: Democracy, inclusiveness, collective agency and locality-based policy. Rural Sociology. 66(1):1-21.

Theodori, G. 2000. Levels of analysis and conceptual clarification in community attachment and satisfaction research: connections to community development. Journal of the Community Development Society 31(1): 35-58.

Theodori, G. 2005. Community and community development in resource-based areas: Operational definitions rooted in an interactional perspective. Society and Natural Resources 18: 661-669.

Torney-Purta, J., Lehmann, R., Oswald, H. \& Schultz, W. 2001. Citizenship and education in 28 countries: Civic knowledge and engagement at age fourteen. Amsterdam, NL: International Association for the Evaluation of Educational Achievement.

vanLinden, J.A. \& Fertman, C.I. 1998. Youth Leadership. San Francisco, CA: Jossey-Bass.

Verba, S., Scholzman, L., \& Brady, H. 1995. Voice and equality: Civic volunteerism in American life. Cambridge, MA: Harvard University Press.

Watts, R.J., Williams, N.C. \& Jagers, R.J. 2005. Sociopolitical development. American Journal of Community Psychology 31(1-2): 185-194.

Wilkinson, K. 1991. The Community in Rural America. New York, NY: Greenwood Press.

Youniss, J., \& Yates, M. 1997. What we know about engendering civic identity. American Behavioral Scientist 40: 620-631.

Zeldin,S., A. K. McDaniel, D. Topitzes, \& M. Calvert. 2000. Integrating research and practice to understand and strengthen communities for adolescent development: An introduction to the special issue and current issues. Applied Developmental Science. 4 (Suppl. 1):2-10.

(C) Copyright of Journal of Youth Development Bridging Research and Practice. Content may not be copied or emailed to multiple sites or posted to a listserv without copyright holder's express written permission. Contact Editor at: patricia.dawson@oregonstate.edu for details. However, users may print, download or email articles for individual use.

ISSN 2325-4009 (Print); ISSN 2325-4017 (Online) 